INTERNATIONAL JOURNAL OF MULTidisciplinARY RESEARCH AND ANALYSis

ISSN(print): 2643-9840, ISSN(online): 2643-9875

Volume 04 Issue 08 August 2021

DOI: 10.47191/ijmra/v4-i8-10, Impact Factor: 6.072

Page No.- 1121-1133

\title{
Entrepreneurship Development Programs and Job Creation in Calabar, Cross River State Nigeria
}

\author{
Ehugbo, Ikechukwu ${ }^{1}$, Ugboko, Lucky Nwakego² \\ ${ }^{1}$ Lecturer, Business Administration and Management, School of Business Studies, Cross River Institute of Technology and \\ Management, Ugep \\ ${ }^{2}$ Finance Director, Cross River Institute of Technology and Management, Ugep
}

\begin{abstract}
The advert of entrepreneurship development has played significant role in provision of employment opportunities both in developing and developed nations. This study investigates the impact of entrepreneurship program on job creations in Nigeria. The study was carried out at Calabar, Cross River State, Nigeria. The study employed Survey research. Cronbach Alpha method was used to determine the reliability at .075 . The study involves 262 small business owners who accepted to be part of the sample population. The selected business field includes; welders (60), tailors (75) and hair salon owners (127) within the city of Calabar. A structured Questionnaire was used as the major instrument in collection of data. Multistage Cluster random sampling was used to determine the sample size. Simple percentage and multiple regression analysis were used to test the hypotheses with the help of SPSS version 25. The results from hypotheses one and two reveals that there a significant and positive relationship between program transparency, program continuity and job creation while result from hypothesis three reveals a significant but negative relationship between youth commitment and job creations. The study therefore, recommended that the organizers of the programs should eliminate every form of bias in training and equipping the trained participants. Entrepreneurship programs should be design with a long term strategic plans so as to ensure sustainability and continuity of such programs. The entrepreneurship program should be design in a way that only person(s) that have passion, zeal and interest in such program should be selected.
\end{abstract}

KEYWORDS: Entrepreneurship, Program Continuity, Program Transparency, Youth Commitment.

\section{INTRODUCTION}

The trend of globalization has given impetus to the spread and development of entrepreneurship among developed and developing nations. No nation can survive without the activities of the entrepreneur. The activities of an entrepreneur is as old as man-kind, from the beginning the first man has the skills and creativity to farm and rare livestock as a source of livelihood. The concept of entrepreneurship has attracted global attention and recognition as a way of revolving and sustaining economic growth and stability of a nation. The knowledge of entrepreneurship allows people to assess and implement its creative skills for his personal and economic development of a nation. Entrepreneurship by way of definition is activities that allow an individual to discover and implement its skills in creation of new product or improvement on the existing product through innovative skills, thereby becoming self-independent. An entrepreneur is a person who is drive with creative and innovative skills, and passionate to become a self-made without depending wholly on government for it survival. Furthermore, an entrepreneur is a person who channels his talent and skills into a productive venture. Entrepreneurship is activities that required extreme sensitivity towards blind opportunities and employing every possible means to create value from the identified opportunities. Blind opportunities are productive ideas that have remain idle over a given period of time without been discovered and implement in solving human and economy problem of a nation. In Nigeria, the issue of entrepreneurship development has been given adequate attention through introduction of indigenization and enterprise promotion Act Of 1972 and its revision in 1977 (Asogwa \& Anah, 2017).

Given the generally held view that entrepreneurship development is the key to poverty eradication, employment generation, and rapid economic development; various governments in Nigeria have, over the past three decades, evolved policies and programs (Idam, 2014) such as Operation Feed the Nation of 1978, the Green Revolution of 1982, the Directorate of Foods Roads and Infrastructure (DFRI), the National Directorate of Employment (NDE), National Poverty Eradication Program (NAPEP), Poverty 


\section{Entrepreneurship Development Programs and Job Creation in Calabar, Cross River State Nigeria}

Alleviation Programs (PAP), the Subsidy Reinvestment and Empowerment Programs (SURE-P), Youth Enterprise With Innovation In Nigeria (YOUWIN), Small and Medium Industries Equity Investment Scheme (SMIEIS), National Economic Empowerment Development Strategy (NEEDS), National Office for Technology Acquisition and Promotion (NOTAP), Raw Materials and Development Council (RMRDC) and the current Social Investment Program. All the programs are geared towards poverty eradication and provision of employment opportunities for the Nigerians. Nevertheless, the programs have not really achieved the expectation to which it was established; as youth unemployment and poverty rate is at red bottom. According to NBS reports of 2019, about 82.9 million of Nigerians are living in poverty and the figure represents 40.09 percent of the total population. This implies that majority of the citizen are living below one United States dollar per day.

Efforts to further deepen entrepreneurship development in Nigeria saw it limelight through introduction of policies on entrepreneurship education into tertiary institutions by the Federal Government of Nigeria through the National Universities Commission (NUC) (Adewusi \& Adisa, 2018). In 2006, the Federal Government gingered the inclusion of entrepreneurship education as a compulsory course for students in all universities (Aliu, 2008). The quest to sustain and improve on the introduced programs, the administration of President Musa Yar'adua implement SAED program into the NYSC scheme in 2008. This is to further re-orientate and introduce the graduate to vast career options instead of waiting for white collar jobs which are limited. In spite of the strategic programs of the government of Nigeria in eradication of poverty and job creations; youth's unemployment are still on the rise.

\section{STATEMENT OF THE PROBLEM}

Entrepreneurship has played crucial role and have constitutes a vital engine in the economic growth and development of a nations; this is because it helps in the stimulation of indigenous entrepreneurship in Nigeria (Paul, 2017). In addition to the role of entrepreneurship, government had on several occasions initiated various programs in a bid to empower and encourage entrepreneurial activities, taking cognizance of the pivotal role it plays in economic development necessary for enhanced standard of living of the people. Yet, the aim for creating the aforementioned programs was defeated orchestrated by the inability of those initiated programs in providing the necessary assistance to entrepreneurs (Asogwa \& Anah, 2017). Furthermore, some the initiated programs by different administrations in Nigeria suffered setback due to lack of continuity, corruptions among the officials who are assigned with such responsibilities, lack of clarity of goals and lack of commitment among the youths. The issue of lack continuity in project delivery is synonymous with Nigeria government and it has negatively affected the economic development of the nation and also has resulted in waste of resource and productive ideas. Many of strategic programs which aimed at mitigating problem of unemployment among graduate have fails due lack continuity in implementation of inherited programs as almost all the regime want to take the glory as originator of a program thereby neglecting the former. Secondly, corruption is a global pandemic that are affecting the economy of both develop and developing countries. Corrupt practices among the trainers and government official in handling fund and equipment meant for effective training and support to various entrepreneurs. Access to capital is considered as one the fundamental problem faced by an entrepreneur in starting up and sustaining his business venture as most of the financial institutions always make it almost impossible to access fund from them due to the terms and condition attached. More so, the inability of the youth to exercise patience and be committed while undergoing such trainings is also a serious concern for the success of the initiative.

Due to the crucial role played by entrepreneurship in economic development of a nation and failure in effective management of entrepreneurship development programs will adversely affect the economic development of Nigeria. To this effect, the present study focused on the necessary factors that will enhance effective management of entrepreneurship development programs in Nigeria.

\section{OBJECTIVES OF THE STUDY}

The general objective of the study is to assess the impact of entrepreneurship development on job creation and poverty eradication in Nigeria

1. To investigate the effect of program continuity on job creations

2. To determine effect of program transparency on job creations

3. To ascertain the effect of youth commitment on job creations

\section{CONCEPT OF ENTREPRENEURSHIP}

Entrepreneur is derived from the French verb "Entrependre" which means to undertake, to attempt, to try in hand, or to contract for (Girard, 1962).The first economist to have used the term entrepreneurship was Richard Cantillion in 1755, a French economist 


\section{Entrepreneurship Development Programs and Job Creation in Calabar, Cross River State Nigeria}

of Irish descent (Holt, 1998). Cantillion is credited with giving the concept of entrepreneurship a central role in economics in analyzing economic development of a nation. Cantillion is attributed as the first person to give the idea of entrepreneurship a vital role in economics, in investigating economic progress of a nation. Cantillion portrayed an entrepreneur as an individual who pays a definite cost for an item to resale it at a hesitant cost, thus making resolution about acquiring and utilizing resources while therefore presumptuous the danger of the venture (Holt, 1998) as referred to by Amadi, Ukoha and Alagah, (2018). According to the business dictionary (2017), the term entrepreneurship is defined as "the capacity and willingness to develop, organize, and manage a business venture along with any of its risks in order to make profits". While it further, describe an entrepreneur to be a person who displays initiative by coordinating business enterprise to obtain profit from the identified opportunity and, as the resolution maker, chooses what, how, and the amount of a product will be created.

Entrepreneurship is the vibrant cycle of vision, transform and creation. It requires utilization of vitality and enthusiasm towards the creation and usage of groundbreaking thoughts and elucidation (Nzewi, Onwuka, \& Onyesom, 2017). An entrepreneur is an originator of an idea, innovator, risk taker, and a dream achiever. As an originator, an entrepreneur is viewed as a person whose idea has lead to establishment of profitable business venture or invention of a solution to a particular societal problem. As innovator, an entrepreneur is viewed as a valuable game charger in business processes, product penchant, efficient utilization of limited resource etc. As a risk taker, an entrepreneur is viewed as one who is willing to undertake known and unknown risk in order to ensure that his dreams and ideas are properly put into use. As dream achiever, an entrepreneur is viewed as one who stops at nothing to ensure that his dreams are achieved. He dreams unimaginable things and ensure actualization of such dream without bias or fear of failure.

According to Usioboh (2008), entrepreneurship is popularly and enthusiastically supported due to its capability to:

1. Create employments through introduction of new ventures, particularly small businesses.

2. Raise efficiency through different types of innovation.

3. Facilitate exchange of technology or the acceptance of existing ones.

4. Harness limited resource that may some way or another stay inactive and put them into profitable use.

5. Stimulate development in those divisions which provides it with inputs.

6. Reinvigorate public and private enterprises, especially small scale businesses.

7. Encourage and maintain economy dynamism that empowers an economy to modify freedom and status for themselves in the public arena.

Oborah (2003) propose that entrepreneurship is an authentic work choice to wage work and panacea to graduate joblessness. In this manner, it is noteworthy for graduates and young people in general to be completely engaged with gaining innovative skills through training and practices while still in school. This will go far to help in budding them to confront challenges in the society (Oluwakemi, Olawale \& Qudus, 2018). However, young people are faced with tight spot of going through entrepreneurship or looking for white cola job. Young entrepreneurs are classifies into two categories: those who are driven by the need to work as an entrepreneur (necessity entrepreneurship); and those driven by the chance to be converted into an entrepreneur (opportunity entrepreneurship) (Lippman, Davis, \& Aldrich, 2005; Williams \& Nadin, 2010).

\section{CONCEPT OF PROGRAM CONTINUITY}

Program continuity is a process or mechanisms that are in place to ensure sustainability of a given entrepreneurial schemes. The process is the systematic arrangements that are adopted in the program formation and process reengineering of the program. The program continuity will lay a proper foundation for the actualization of the dreams of the entrepreneurs through constant innovation and consistence in the training processes. Healthy financial condition is very vital in the sustainability of any program (Boyer \& Blazy, 2014). However, it is pertinent to know that finance may not guarantee the continuity if the motive behind the program is not well defined.

\section{CONCEPT OF PROGRAM TRANSPARENCY}

Transparency is the act of being honest in handling any tasks. Program transparency involves the proper selection, training and distribution of equipment to successful trained entrepreneur without bias. Relevant information timely disclosure can establish transparency and reliance on an institution (Wehmeier \& Raaz, 2012). In the study of Lee and Joseph (2013) they investigated web disclosure practices and their links to organizational transparency. They concluded that organizations that openly disclose their information to the public through their website are considered to be trustworthy, open and accountable (Lee \& Joseph, 2013). However, transparency of entrepreneurship program will guarantee the success and reduce the unnecessary cost attach to the program. Success and failure of any entrepreneurship programs depend on the transparency of the organizer. 


\section{Entrepreneurship Development Programs and Job Creation in Calabar, Cross River State Nigeria}

\section{CONCEPT OF YOUTH COMMITMENT}

Youth commitment involves the ability of the young people to accept and engage on certain innovative ideas, skills and knowledge that will enhance their creative and productive proficiency. Presently, the youth undergoes extreme transformation processes that are filled with uncertainty (Furlong \& Cartmel, 2007). Most of the entrepreneurial programs are risk intensive in nature but are profitable when right approaches are applied, which may required dedications form the participants. Uncertainty is a condition that births entrepreneurship, yet the ability to transform the uncertain situation into a productive venture is the sole responsibility of an entrepreneur (Lewin, 2012). To suffice, the entrepreneurship process is a period whereby youth understands that they commitment to accomplish their ideas will transmit to better transformations in human wellbeing, consequently they will regularly improve on their model and business plans (Rahmatiah \& Wiroto, 2019). Furthermore, Young are faced with numerous challenges concerning the choice of career to make, either to become a potential job seeker or an entrepreneur.

\section{THEORETICAL FRAMEWORK}

Basically, entrepreneurship theories are rooted in multi-discipline perceptive, which are Economic, Psychology, Sociology, Anthropology, and Management. This study was anchored on entrepreneurial management theories. The management entrepreneurial theories comprises of Opportunity-Based entrepreneurship theory and Resource-Based entrepreneurship theory. The theory of Opportunity-Based theory was propounded by Peter Drucker and Howard Stevenson after given constructive criticisms about Economic theory of entrepreneurship in 1985 and 1990 respectively. Opportunity-Based theory gives an extensive theoretical structure for entrepreneurial research (Fiet, 2002; Shane, 2000). Change does not actually caused by an entrepreneur as (claimed by Schumpeterian or Austrian school) but takes advantage of the identified opportunities that causes change (in process re-engineering, consumer preference, technology etc) (Drucker, 1985). He additional gives his own presumption of who an entrepreneur is; as indicated by Drucker, (1985), an entrepreneur is an individual who consistently looks for change, reacts to it, and takes advantage of it as opportunity. What is perceptible in Drucker's opportunity construct is that entrepreneurs are more focused on the possibilities created by change than the problems (Kwabena, 2011). Stevenson and Harmeling (1990) broaden on Drucker's opportunity-based theory to incorporate resourcefulness. He went on to conclude that the core goal of entrepreneurial management is in their "quest to identify new opportunity regardless of resources presently controlled" (pp.2). This entails that an entrepreneur is more interested in efficient utilization of limited resource with regards to change in formal processes through which new opportunity are identified. Resource-Based Theory of entrepreneurship advocates that the ability of an entrepreneur to have access to resources is a significant predictor of opportunity-based entrepreneurial management and new business venture growth (Alvarez \& Busenitz, 2001).This theory recognized the significant of financial availability, social connectivity and human resource in growing a new venture (Aldrich, 1999).

\section{METHODOLOGY}

Survey research design was employed for the study. The study was carried out at Calabar, Cross River State, Nigeria. The study involves 262 small business owners who accepted to be part of the sample population. The selected business field includes; welders (60), tailors (75) and hair salon owners (127) within the city of Calabar. A structured Questionnaire was used as a major instrument in collection of data. Multistage Cluster random sampling was used to determine the sample size. Cronbach Alpha reliability method was used to determine the reliability of the instrument. Simple percentage and multiple regression analysis were used to test the hypotheses.

\section{Data Analysis, Hypothesis Testing and Discussion of Findings}

Table 1.1

\begin{tabular}{|c|c|c|c|c|c|}
\hline \multicolumn{6}{|c|}{ Gender } \\
\hline & & Frequency & Percent & Valid Percent & Cumulative Percent \\
\hline \multirow[t]{3}{*}{ Valid } & Male & 156 & 66.1 & 66.1 & 66.1 \\
\hline & Female & 80 & 33.9 & 33.9 & 100.0 \\
\hline & Total & 236 & 100.0 & 100.0 & \\
\hline
\end{tabular}

Source: Field survey, (2020) 
Entrepreneurship Development Programs and Job Creation in Calabar, Cross River State Nigeria

Table 1.2

\begin{tabular}{|c|c|c|c|c|c|}
\hline \multicolumn{6}{|l|}{ Age } \\
\hline & & Frequency & Percent & Valid Percent & Cumulative Percent \\
\hline \multirow[t]{6}{*}{ Valid } & 10-20years & 36 & 15.3 & 15.3 & 15.3 \\
\hline & 21-30years & 99 & 41.9 & 41.9 & 57.2 \\
\hline & 31-40years & 68 & 28.8 & 28.8 & 86.0 \\
\hline & 41-50years & 30 & 12.7 & 12.7 & 98.7 \\
\hline & 51years and above & 3 & 1.3 & 1.3 & 100.0 \\
\hline & Total & 236 & 100.0 & 100.0 & \\
\hline
\end{tabular}

Source: Field survey, (2020)

Table 1.3

\section{Educational Qualification}

\begin{tabular}{lll|l|l|l} 
& & & & \\
& & & & \\
Valid & FSLC & 30 & Percent & Valid Percent & Cumulative Percent \\
\cline { 2 - 5 } & SSCE & 65 & 12.7 & 12.7 & 12.7 \\
\cline { 2 - 5 } & NCE/OND & 45 & 27.5 & 27.5 & 40.3 \\
\hline HND & 15 & 19.1 & 19.1 & 59.3 \\
\hline BSC & 81 & 6.4 & 6.4 & 65.7 \\
\hline Total & 236 & 34.3 & 34.3 & 100.0 \\
\hline
\end{tabular}

Source: Field survey, (2020)

Table 1.4

Empowerment Process

\begin{tabular}{|c|c|c|c|c|c|}
\hline & & Frequency & Percent & Valid Percent & Cumulative Percent \\
\hline \multirow[t]{5}{*}{ Valid } & Government/NGO & 183 & 77.5 & 77.5 & 77.5 \\
\hline & s & & & & \\
\hline & Relatives & 30 & 12.7 & 12.7 & 90.3 \\
\hline & Self & 23 & 9.7 & 9.7 & 100.0 \\
\hline & Total & 236 & 100.0 & 100.0 & \\
\hline
\end{tabular}

Source: Field survey, (2020)

Table 1.5

\section{Employment Field}

\begin{tabular}{lll|l|l|l} 
& & & \\
& & & \\
& & & \\
& & & \\
Valid & Welder & 60 & Percent & Valid Percent & Cumulative Percent \\
\cline { 2 - 5 } & Tailor & 74 & 25.4 & 25.4 & 25.4 \\
\cline { 2 - 6 } & Salon & 102 & 31.4 & 31.4 & 56.8 \\
\cline { 2 - 5 } & Total & 236 & 100.0 & 13.2 & 100.0 \\
\hline
\end{tabular}

Source: Field survey, (2020)

Table 1.1 shows the distribution by gender. 156 (66.1\%) percent of the respondents were male and 80 (33.9\%) percent were female. This indicates that the proportion of male in entrepreneurship activities is more than the female. This also entails that men are more interested in developing themselves through entrepreneurship than the women. 


\section{Entrepreneurship Development Programs and Job Creation in Calabar, Cross River State Nigeria}

Table 1.2 reveals the distribution of respondents by age. Out of 236 respondents, 36 (15.3\%) were between $10-20$ years, 99 (41.9\%) were between $21-30$ years, 68 (28.8\%) were between 31-40 years, 30(12.7\%) were between $41-50$ years, 3 (1.3\%) were between 51 years and above. The majority of the respondents were between the ages of 21 and 30 years. These indicate that youth between the age of 21 and 30years are more active and interested in developing their entrepreneurial skills.

Table 1.3 reveals that, out of 236 respondents 30 representing $12.7 \%$ have FSLC, 65 respondents representing $27.5 \%$ have SSCE, 45 respondents representing $19.1 \%$ have NCE/OND, 15 respondents representing $6.4 \%$ have HND, followed by the 81 respondents representing $34.3 \%$ BSc. The majority of the entrepreneurs are BSc holders. These indicate that at that level of education, majority of them have acquired knowledge about entrepreneurship and the need to develop and improves on themselves without waiting for limited white cola job.

Table 1.4 shows that out of 236 respondents 183 (77.5\%) were empowered by government and NGOs, 30(12.7\%) were empowered by relatives, followed by 23 respondents representing $9.7 \%$ were empowered by self. From the analysis it shows that Government and NGOs through its various programs has actually empowered the youths in different field of endeavor.

Table 1.5 shows the distribution of respondents by employment field. Out of 236 respondents 60 (25.4\%) represents entrepreneurs that belong to welding and constructions field, 74 (31.4\%) representing entrepreneurs that belong to fashion designs, 102 (43.2\%) representing entrepreneurs that belongs to hair salon. These reflect the class of entrepreneurs that are eligible for study of this nature.

This section presents the data analysis, interpretation and findings in order of the three specific objectives of the study. The responses were analyzed based on the frequencies and descriptive statistics. The questionnaire responses were based on a six Likert scale with numerical values for ease of data analysis.

The values assigned to the Likert scale were 1= Strongly Disagree (SD), 2= Disagree (D), 3= Undecided (U), 4=Partial Agreed (PA), 5= Agree (A), 6= Strongly Disagree (SD).

Table 1.6

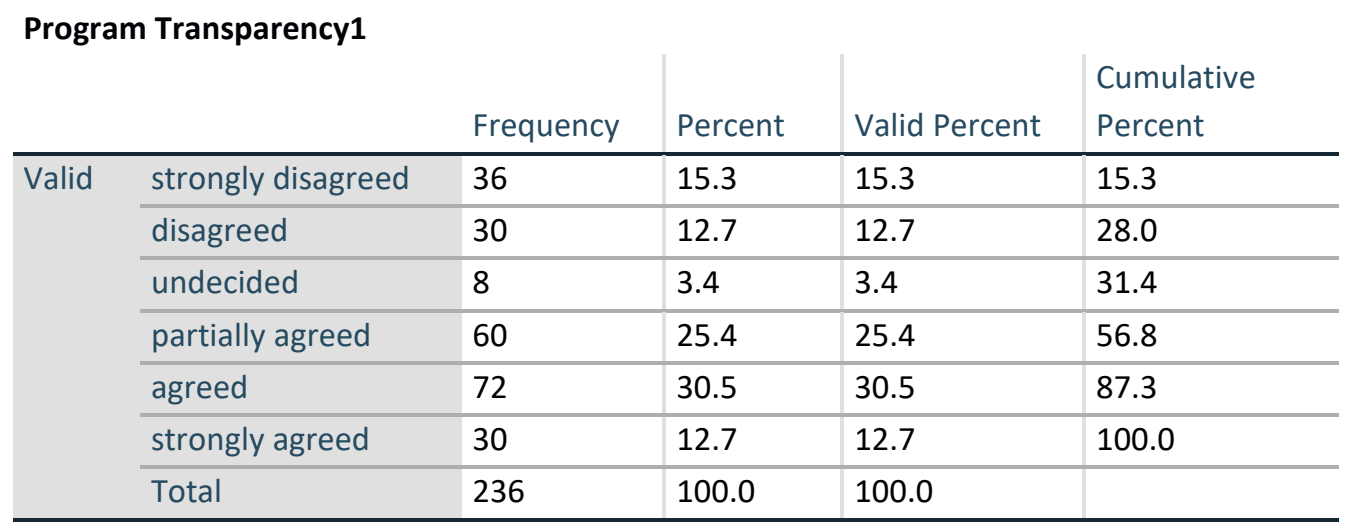

\section{Program Transparency2}

\begin{tabular}{lll|l|l|l} 
& & & & & Cumulative \\
& & Frequency & Percent & Valid Percent & Percent \\
\hline Valid & strongly disagreed & 39 & 16.5 & 16.5 & 16.5 \\
\cline { 2 - 6 } & disagreed & 86 & 36.4 & 36.4 & 53.0 \\
\cline { 2 - 6 } & undecided & 9 & 3.8 & 3.8 & 56.8 \\
\hline partially agreed & 60 & 25.4 & 25.4 & 82.2 \\
\hline agreed & 31 & 13.1 & 13.1 & 95.3 \\
\hline strongly agreed & 11 & 4.7 & 4.7 & 100.0 \\
\hline Total & 236 & 100.0 & 100.0 & \\
\hline
\end{tabular}

Program Transparency3

\begin{tabular}{lll|l|l|l} 
& & & & & \multicolumn{2}{c}{ Cumulative } \\
& & Frequency & Percent & Valid Percent & Percent \\
\hline Valid & strongly disagreed & 30 & 12.7 & 12.7 & 12.7 \\
\cline { 2 - 6 } & disagreed & 43 & 18.2 & 18.2 & 30.9 \\
\hline
\end{tabular}


Entrepreneurship Development Programs and Job Creation in Calabar, Cross River State Nigeria

\begin{tabular}{l|l|l|l|l}
\hline undecided & 27 & 11.4 & 11.4 & 42.4 \\
\hline partially agreed & 59 & 25.0 & 25.0 & 67.4 \\
\hline agreed & 50 & 21.2 & 21.2 & 88.6 \\
\hline strongly agreed & 27 & 11.4 & 11.4 & 100.0 \\
\hline Total & 236 & 100.0 & 100.0 & \\
\hline
\end{tabular}

Table 1.6 depicts respondents' opinion on the transparency and training and equipping entrepreneurs. The first items in table 1.6 shows that 30(12.7 percent) of the respondents strongly agreed that entrepreneurship training programs are done by professionals, while 72(30.5 percent) agreed, 60(25.4 percent) partially agreed, 8 (3.4 percent) were undecided, 30(12.7 percent) disagreed and 36(15.3 percent) strongly disagreed to the issue. These shows that majority of the respondents agreed that the entrepreneurship training programs are done by professionals. Furthermore, this also depicted that government are doing their best in training the youths through the use of expert in order to enable them compete favorably in the society.

The second item in table 1.6 shows that 11 (4.7 percent) of the respondents strongly agreed that the training durations are enough for an entrepreneurs to be equipped with necessary knowledge and skills, while 31(13.1 percent) agreed, 60(25.4 percent) partially agreed, 9(3.8 percent) were undecided, 86(36.4 percent) disagreed and 39(16.5percent) strongly disagreed to the issue. This affirm that majority of the respondents disagreed that the training durations are enough for an entrepreneurs to be equipped with necessary knowledge and skills. The government through its agency should make a review on the training time duration so as to adequately equip the entrepreneurs with proper information on their choose career.

The third item in table 1.6 shows that $27(11.4$ percent) of the respondents strongly agreed that everybody are treated equal on the process of empowering the trained entrepreneurs, while 50(21.2 percent) agreed, 59(25.0 percent) partially agreed, 27(11.4 percent) were undecided, 43(18.2 percent) disagreed and 30(12.7 percent) strongly disagreed to the issue. This indicate that majority of the respondents agreed that everybody are treated equal on the process of empowering the trained entrepreneurs. The entrepreneurs should be equipped based on the area of their competency. The rating measures should be unbiased so as to select the most competency and qualified candidate to empower.

Table 1.7

\begin{tabular}{|c|c|c|c|c|c|}
\hline \multicolumn{6}{|c|}{ Program Continuity1 } \\
\hline & & Frequency & Percent & Valid Percent & $\begin{array}{l}\text { Cumulative } \\
\text { Percent }\end{array}$ \\
\hline \multirow[t]{7}{*}{ Valid } & strongly disagreed & 6 & 2.5 & 2.5 & 2.5 \\
\hline & Disagreed & 11 & 4.7 & 4.7 & 7.2 \\
\hline & Undecided & 22 & 9.3 & 9.3 & 16.5 \\
\hline & partially agreed & 70 & 29.7 & 29.7 & 46.2 \\
\hline & Agreed & 87 & 36.9 & 36.9 & 83.1 \\
\hline & strongly agreed & 40 & 16.9 & 16.9 & 100.0 \\
\hline & Total & 236 & 100.0 & 100.0 & \\
\hline
\end{tabular}

\section{Program Continuity2}

\begin{tabular}{|c|c|c|c|c|c|}
\hline & & Frequency & Percent & Valid Percent & $\begin{array}{l}\text { Cumulative } \\
\text { Percent }\end{array}$ \\
\hline \multirow[t]{7}{*}{ Valid } & strongly disagreed & 7 & 3.0 & 3.0 & 3.0 \\
\hline & Disagreed & 22 & 9.3 & 9.3 & 12.3 \\
\hline & Undecided & 21 & 8.9 & 8.9 & 21.2 \\
\hline & partially agreed & 48 & 20.3 & 20.3 & 41.5 \\
\hline & Agreed & 78 & 33.1 & 33.1 & 74.6 \\
\hline & strongly agreed & 60 & 25.4 & 25.4 & 100.0 \\
\hline & Total & 236 & 100.0 & 100.0 & \\
\hline
\end{tabular}




\section{Entrepreneurship Development Programs and Job Creation in Calabar, Cross River State Nigeria}

Program Continuity3

\begin{tabular}{lll|l|l|l} 
& & & & & Cumulative \\
& & Frequency & Percent & Valid Percent & Percent \\
\hline Valid & strongly disagreed & 6 & 2.5 & 2.5 & 2.5 \\
\cline { 2 - 6 } & Disagreed & 8 & 3.4 & 3.4 & 5.9 \\
\cline { 2 - 6 } & Undecided & 19 & 8.1 & 8.1 & 14.0 \\
\hline partially agreed & 64 & 27.1 & 27.1 & 41.1 \\
\hline Agreed & 91 & 38.6 & 38.6 & 79.7 \\
\hline strongly agreed & 48 & 20.3 & 20.3 & 100.0 \\
\hline Total & 236 & 100.0 & 100.0 & \\
\hline
\end{tabular}

Table 1.7 depicts respondents' opinion on the programs continuity and entrepreneurship development. The first items in table 1.7 shows that 40 (16.9 percent) of the respondents strongly agreed that the programs are designed to be continuous in nature, while 87(36.9 percent) agreed, 70(29.7 percent) partially agreed, 22(9.3 percent) were undecided, 11(4.7 percent) disagreed and 6(2.5 percent) strongly disagreed to the issue. These shows that majority of the respondents agreed that the programs are designed to be continuous in nature. Furthermore, this also depicted that the various governmental programs are in line with the needs of the people as that will help to curb the rate of unemployment among the youths and also prepare the youth against globe economic crisis.

The second item in table 1.7 shows that 60 (25.4 percent) of the respondents strongly agreed that the sustainability of the established government programs are influenced by availability of fund, while 78(33.1 percent) agreed, 48(20.3 percent) partially agreed, 21(8.9 percent) were undecided, 22(9.3 percent) disagreed and 7(3.0 percent) strongly disagreed to the issue. This affirm that majority of the respondents agreed that the sustainability of the established government programs are influenced by availability of fund. Government should make fund available for any of the established entrepreneurship programs as that will enable the continuity of the programs, which will in turn ensure actualization of the purpose to which it was established.

The third item in table 1.7 shows that $48(20.3$ percent) of the respondents strongly agreed that the management dynamic of the established programs are influenced by the economic needs of the people and the nation, while 91(38.6 percent) agreed, 64(27.1 percent) partially agreed, 19 (8.1 percent) were undecided, 8(3.4 percent) disagreed and 6(2.5 percent) strongly disagreed to the issue. This indicate that majority of the respondents agreed that the management dynamic of the established programs are influenced by the economic needs of the people and the nation. The globe economic needs will always be considered in establishing any entrepreneurship programs. This is to enable Nigerian to meet up contemporary globe business activities as that will then remain relevant in globe market.

Table 1.8

\begin{tabular}{|c|c|c|c|c|c|}
\hline & & Frequency & Percent & Valid Percent & $\begin{array}{l}\text { Cumulative } \\
\text { Percent }\end{array}$ \\
\hline \multirow[t]{7}{*}{ Valid } & strongly disagreed & 6 & 2.5 & 2.5 & 2.5 \\
\hline & Disagreed & 58 & 24.6 & 24.6 & 27.1 \\
\hline & Undecided & 8 & 3.4 & 3.4 & 30.5 \\
\hline & partially agreed & 64 & 27.1 & 27.1 & 57.6 \\
\hline & Agreed & 93 & 39.4 & 39.4 & 97.0 \\
\hline & strongly agreed & 7 & 3.0 & 3.0 & 100.0 \\
\hline & Total & 236 & 100.0 & 100.0 & \\
\hline
\end{tabular}

Youth Commitment2

\begin{tabular}{lll|l|l|l} 
& & & & \multicolumn{2}{l}{$\begin{array}{l}\text { Cumulative } \\
\end{array}$} \\
& Frequency & Percent & Valid Percent & Percent \\
\hline Valid & strongly disagreed & 19 & 8.1 & 8.1 & 8.1 \\
\cline { 2 - 6 } & Disagreed & 40 & 16.9 & 16.9 & 25.0 \\
\cline { 2 - 6 } & Undecided & 34 & 14.4 & 14.4 & 39.4 \\
\hline
\end{tabular}


Entrepreneurship Development Programs and Job Creation in Calabar, Cross River State Nigeria

\begin{tabular}{l|l|l|l|l}
\hline partially agreed & 78 & 33.1 & 33.1 & 72.5 \\
\hline Agreed & 46 & 19.5 & 19.5 & 91.9 \\
\hline strongly agreed & 19 & 8.1 & 8.1 & 100.0 \\
\hline Total & 236 & 100.0 & 100.0 & \\
\hline
\end{tabular}

\begin{tabular}{|c|c|c|c|c|c|}
\hline \multicolumn{6}{|c|}{ Youth Commitment3 } \\
\hline & & Frequency & Percent & Valid Percent & $\begin{array}{l}\text { Cumulative } \\
\text { Percent }\end{array}$ \\
\hline \multirow[t]{7}{*}{ Valid } & strongly disagreed & 9 & 3.8 & 3.8 & 3.8 \\
\hline & Disagreed & 38 & 16.1 & 16.1 & 19.9 \\
\hline & Undecided & 8 & 3.4 & 3.4 & 23.3 \\
\hline & partially agreed & 46 & 19.5 & 19.5 & 42.8 \\
\hline & Agreed & 86 & 36.4 & 36.4 & 79.2 \\
\hline & strongly agreed & 49 & 20.8 & 20.8 & 100.0 \\
\hline & Total & 236 & 100.0 & 100.0 & \\
\hline
\end{tabular}

Table 1.8 depicts respondents' opinion on the youth's commitment and entrepreneurship development. The first items in table 1.8 shows that $7(3.0$ percent) of the respondents strongly agreed that youths are interested and appreciate the established government empowerment programs, while 93(39.4 percent) agreed, 64(27.1 percent) partially agreed, 8(3.4 percent) were undecided, 58(24.6 percent) disagreed and $6(2.5$ percent $)$ strongly disagreed to the issue. These shows that majority of the respondents agreed that the youths are interested and appreciate the established government empowerment programs. Furthermore, this also depicted that the various governmental entrepreneurial programs are serving the purpose to which it was established due to active involvement of youths.

The second item in table 1.8 shows that 19(8.1 percent) of the respondents strongly agreed that the empowered youths are making progress on their trained career through training of other youths, while 46(19.5 percent) agreed, 78(33.1 percent) partially agreed, 34(14.4 percent) were undecided, 40(16.9 percent) disagreed and 19(8.1 percent) strongly disagreed to the issue. This affirm that majority of the respondents agreed that the empowered youths are making progress on their trained career through training of other youths. The progressive career of an entrepreneur is determined through its ability to train others on the same job.

The third item in table 1.8 shows that 49 (20.8 percent) of the respondents strongly agreed that the trained youths serves as source of encouragement to other youths to be self-employed, while 86(36.4 percent) agreed, 46(19.5 percent) partially agreed, 8(3.4 percent) were undecided, 38(16.1 percent) disagreed and 9(3.8 percent) strongly disagreed to the issue. This indicate that majority of the respondents agreed that the trained youths serves as source of encouragement to other youths to be self-employed. Youths are happy doing their jobs and making profit without depending on government for support. Training the youths on the best way to go on their choice of career will help in reducing the rate of unemployment.

Table 1.9

Job Creation1

\begin{tabular}{lll|l|l||l} 
& & & & Cumulative \\
& & Frequency & Percent & Valid Percent & Percent \\
\hline Valid & strongly disagreed & 7 & 3.0 & 3.0 & 3.0 \\
\cline { 2 - 6 } & Disagreed & 22 & 9.3 & 9.3 & 12.3 \\
\cline { 2 - 6 } & Undecided & 21 & 8.9 & 8.9 & 21.2 \\
\hline partially agreed & 48 & 20.3 & 20.3 & 41.5 \\
\hline Agreed & 78 & 33.1 & 33.1 & 74.6 \\
\hline strongly agreed & 60 & 25.4 & 25.4 & 100.0 \\
\hline Total & 236 & 100.0 & 100.0 & \\
\hline
\end{tabular}


Entrepreneurship Development Programs and Job Creation in Calabar, Cross River State Nigeria

Job Creation2

\begin{tabular}{lll|l|l|l} 
& & & & & Cumulative \\
& & Frequency & Percent & Valid Percent & Percent \\
\hline Valid & strongly disagreed & 6 & 2.5 & 2.5 & 2.5 \\
\cline { 2 - 6 } & Disagreed & 8 & 3.4 & 3.4 & 5.9 \\
\cline { 2 - 6 } & Undecided & 19 & 8.1 & 8.1 & 14.0 \\
\hline partially agreed & 64 & 27.1 & 27.1 & 41.1 \\
\hline Agreed & 91 & 38.6 & 38.6 & 79.7 \\
\hline strongly agreed & 48 & 20.3 & 20.3 & 100.0 \\
\hline Total & 236 & 100.0 & 100.0 & \\
\hline
\end{tabular}

Job Creation3

\begin{tabular}{|c|c|c|c|c|c|}
\hline & & Frequency & Percent & Valid Percent & $\begin{array}{l}\text { Cumulative } \\
\text { Percent }\end{array}$ \\
\hline \multirow[t]{7}{*}{ Valid } & strongly disagreed & 9 & 3.8 & 3.8 & 3.8 \\
\hline & Disagreed & 38 & 16.1 & 16.1 & 19.9 \\
\hline & Undecided & 8 & 3.4 & 3.4 & 23.3 \\
\hline & partially agreed & 46 & 19.5 & 19.5 & 42.8 \\
\hline & Agreed & 86 & 36.4 & 36.4 & 79.2 \\
\hline & strongly agreed & 49 & 20.8 & 20.8 & 100.0 \\
\hline & Total & 236 & 100.0 & 100.0 & \\
\hline
\end{tabular}

The first item in table 1.9 shows that 60 (25.4 percent) of the respondents strongly agreed that the Jobs are created through entrepreneurship programs, while 78(33.1 percent) agreed, 48(20.3 percent) partially agreed, 21(8.9 percent) were undecided, 22(9.3 percent) disagreed and 7(3.0 percent) strongly disagreed to the issue. This affirm that majority of the respondents agreed that the Jobs are created through entrepreneurship programs. Entrepreneurship should be continuous activities of government as that will help in generating and reducing the rate of employment among youths.

The second item in table 1.9 shows that 48(20.3 percent) of the respondents strongly agreed that Youths are given opportunity to showcase and improve on their various skills, while 91(38.6 percent) agreed, 64(27.1 percent) partially agreed, 19(8.1 percent) were undecided, 8(3.4 percent) disagreed and 6(2.5 percent) strongly disagreed to the issue. This indicate that majority of the respondents agreed that Youths are given opportunity to showcase and improve on their various skills. Entrepreneurship development program of the government should be encouraged and sustained as that will help the youth in making adequate use of the skills and talents.

The third item in table 1.9 shows that 49(20.8 percent) of the respondents strongly agreed that Youths are trained on how to make profits with their skills and talent, while 86(36.4 percent) agreed, 46(19.5 percent) partially agreed, 8(3.4 percent) were undecided, 38(16.1 percent) disagreed and 9(3.8 percent) strongly disagreed to the issue. This indicate that majority of the respondents agreed that Youths are trained on how to make profits with their skills and talent. Profit maximization can only be attained when the individual the actual value of his products. In this case entrepreneurship programs always trained the youth on the best way to adequate utilize and profit with their skills.

Table 1.10

\begin{tabular}{|c|c|c|c|c|c|}
\hline \multicolumn{6}{|c|}{ Model Summary } \\
\hline Model & $\mathrm{R}$ & R Square & Adjusted R Square & $\begin{array}{l}\text { Std. Error of the } \\
\text { Estimate }\end{array}$ & Durbin-Watson \\
\hline 1 & $.676^{a}$ & .457 & .450 & .47662 & .101 \\
\hline
\end{tabular}

a. Predictors: (Constant), program transparency, program continuity, youth commitment

b. Dependent Variable: job creations

Source: SPSS Output, (2020) 


\section{Entrepreneurship Development Programs and Job Creation in Calabar, Cross River State Nigeria}

Table 1.11

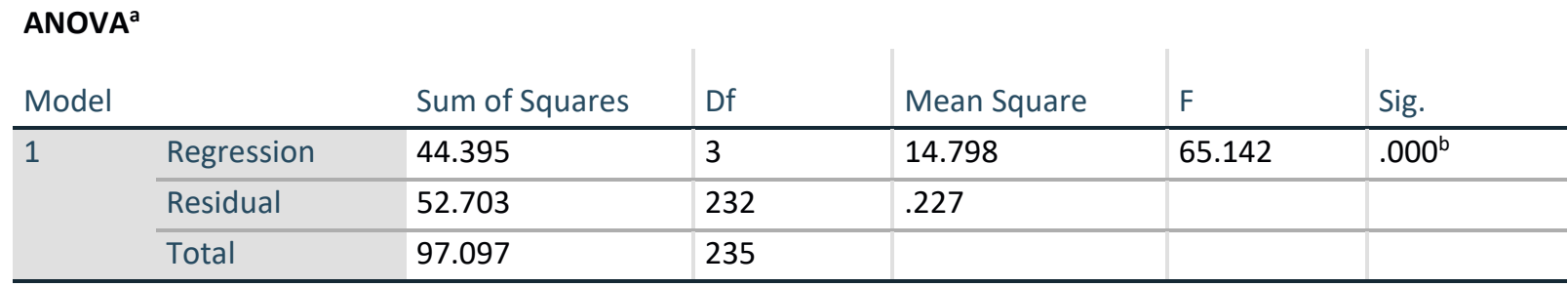

a. Dependent Variable: job creations

b. Predictors: (Constant), program transparency, program continuity, youth commitment

Source: SPSS Output, (2020)

Table 1.12

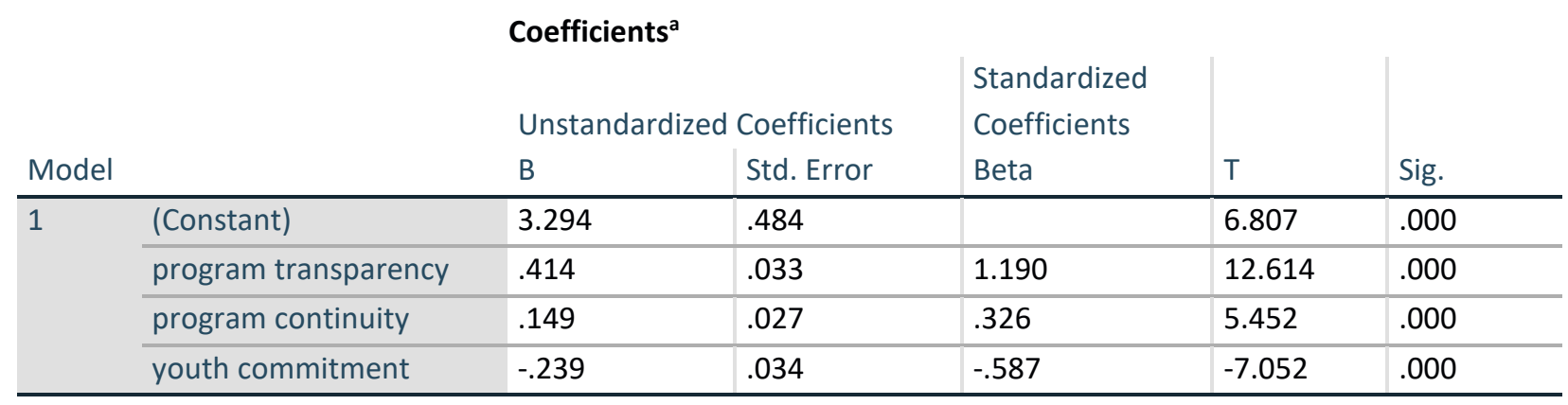

a. Dependent Variable: job creations

Source: SPSS Output, (2020)

The regression tables (Table 1.10, 1.11 and 1.12) program transparency, program continuity and youth's commitment variable being evaluated for its ability to influence job creation. Table 4.10 which is the model summary reveal that the relationship between program transparency, program continuity and youth's commitment and job creations is 67.6 percent (as seen in the $R$ column) given an indication that there is a moderate linear relationship between the two variables. The adjusted $R^{2}$ value (.450) signifies that up to 45.0 percent of job creation is predicted by program transparency, program continuity and youth's commitment and 32.4 percent is unexplained by the model. It implies that 67.6 percent of variation in program transparency, program continuity and youth's commitment can be explained by a unit change in job creation while the remaining 32.4 percent is explained by other variables. The adjusted $R^{2}$ of .450 which is slightly lower than the $R^{2}$ value with 0.001 is a precise indicator of the relationship the independent and dependent variable because it shows moderate sensitive to the addition of irrelevant variable. The F-test $(65.142, p<0.05)$ of the relationship in Table 1.11 indicates that the overall prediction of the independent variable to the dependent variable is statistically significant, therefore, the regression model is a good fit for the data and provides sufficient evidence to conclude that program transparency, program continuity and youth's commitment has a significant influence on the job creation.

Analysis of the regression model coefficients is shown in the Table 1.12 the regression coefficient $(B)$, the intercept $(\alpha)$, and the significance of coefficient in the model is subjected to the t-test to test the null hypothesis that the coefficient is zero. From the table it can be seen that program transparency and program continuity has a significant and positive influence on job creations as the $P$ - value is less than 0.05 significance and positive $t$-value ( $t=12.614$ and 5.452 respectively). Furthermore, the estimated coefficient (.414 and .149 respectively) shows that program transparency and program continuity has a moderate influence on job creations. Therefore, the null hypothesis is rejected and it is concluded that there is a significant and positive relationship between program transparency, program continuity and job creations. The youth's commitment has a significant but negative influence on job creations as the $P$-value is less than 0.05 significance and negative $t$ - value $(t=-7.052)$. Furthermore, the estimated coefficient (-.239) shows that youth's commitment has a weak influence on job creations. Therefore, the null hypothesis is rejected and it is concluded that there is a significant but negative relationship between youth's commitment and job creations.

\section{CONCLUSIONS}

Over the year government of Nigeria has introduce serials of entrepreneurial programs with the aim of creating jobs for the youth's and eradicating poverty from the society. Entrepreneurship development programs in Nigeria are believed to have impacted and contributed to social/economic development of the nation and acceleration of employment generation among youths. 


\section{Entrepreneurship Development Programs and Job Creation in Calabar, Cross River State Nigeria}

Entrepreneurship development is a process of initiating and improving on the talent and skills of an entrepreneur. The knowledge of entrepreneurship development will help prospective entrepreneurs/investors to always take calculative risks and also locate appropriate market for their product.

\section{RECOMMENDATIONS}

1. Entrepreneurship programs should be organized with aimed of eradicating poverty and ensuring sustainable employment creations through employing professional conduct. The organizers of the programs should eliminate every form of bias in training and equipping the trained participants. The implication is that by the way of training and equipping the trained entrepreneurs with actual facilities that will enable them to practices their jobs with minimum risks as secret behind success and failure of such businesses has been revealed to them.

2. Entrepreneurship programs should be design with a long term strategic plans so as to ensure sustainability and continuity of such programs, and should also be back up with transition law in order compel the incoming government to continue with such program rather than incurring the huge cost of setting up another program. The implication is that the process of continuous practices of the same program will give room for improvement and alignment with the contemporary needs of the society at a minimum cost.

3. The entrepreneurship program should be design in a way that only person(s) that have passion, zeal and interested in such program should be selected. The implication is that it will enable agencies to reduce that rate of uncommitted person(s) in the program, thereby saving cost for the organizers and also given room for the right person(s) to be selected and trained

\section{REFERENCE}

1) Adewusi, O. A., \& Adisa, B. I. (2018). The skill acquisition and entrepreneurship development program among corps members in Ibadan, Nigeria. Zaria Sociological Journal, 5(1), 248-260

2) Aldrich, H. E. (1999). Organizations' evolving. Thousand Oaks, CA: Sage Publications

3) Aliu, S. (2008). Recent trends in entrepreneurship education in Nigeria: Prospects and challenges. Retrieved from www.isbe.org.uk

4) Alvarez, S., \& Busenitz, L. (2001). The entrepreneurship of resource based theory. Journal of Management, 27(6), 755775.

5) Asogwa, O. S., \& Anah, S. A. (2017). Impact of entrepreneurship development on economic growth of Enugu State: A study of registered entrepreneurs in Enugu state, Nigeria. International Journal of Economics, Business and Management Research, 1(2), 227-242.

6) Boyer, T., \& Blazy, R. (2014). Born to be alive? The survival of innovative and non-innovative French micro-start-ups. Small Business Economics, 42(4), 669-683.

7) Drucker, P. F. (1985).Innovation and entrepreneurship. New York: Harper \& Row Publishers

8) Fiet, J. O. (2002). The systematic search for entrepreneurial discoveries. Westport, CT: Quorum Books

9) Furlong, A., \& Cartmel, F. (2007). Young People and Social Change: New Perspectives. Berkshire: Open University Press.

10) Girard, D. (1962). The new casselli’s French dictionary. New York: Funk and Wagnalls.

11) Holt D. H. (1998). Entrepreneurship: New venture creation. New Delhi: Prentice, Hall of India Private Limited.

12) Idam, L. E. (2014). Entrepreneurship development in Nigeria: A review. IOSR Journal of Business and Management, 16(1), 1-7

13) Kwabena, N. S. (2011). Entrepreneurship theories and empirical research: A summary review of the literature. European Journal of Business and Management, 3(6), 1-8.

14) Lee, R. L., \& Joseph, R. C. (2013). An examination of web disclosure and organizational transparency. Computers in Human Behavior, 29, 2218- 2224.

15) Lewin, P. (2012). What do we know for certain about uncertainty? Issues of economic risk and uncertainty. Mayfair, London: The Legatum Institute Charles Street Symposium.

16) Lippman, S., Davis, A., \& Aldrich, H. E. (2005). Entrepreneurship and Inequality. In L. A. Keister (Ed.), Research in the Sociology of Work (15): Entrepreneurship (pp. 3-31).

17) Nzewi, H. N., Onwuka, E. M., \& Onyesom, M. (2017). Entrepreneurship evolution and the growth of small scale businesses in Nigeria. Journal of Business and Economic Development, 2(3), 1-7

18) Oborah, A. (2003). Entrepreneurship: Panacea for growth of accounting firms. The Nigerian Accountant, $27(1), 7-9$. 


\section{Entrepreneurship Development Programs and Job Creation in Calabar, Cross River State Nigeria}

19) Okeke, M. I., \& Eme, O. I. (2014). Challenges facing entrepreneurs in Nigeria. Singaporean Journal of Business Economics and Management Studies, 3(5), 18-34.

20) Paul B. I. (2017). Assessing entrepreneurship education for skill acquisition and job generation by business education students in Bayelsa state, Nigeria. International Journal of Education, Culture and Society, 2(1), 1-5.

21) Rahmatiah, Wiroto, D. W., \& Taan, H. (2019). Business continuity, motivation, and social conditions of young entrepreneurs. Economics and Sociology, 12(4), 166- 182.

22) Shane, S. (2000). Prior knowledge and the discovery of entrepreneurial opportunities. Organisation Science, 11, $448-469$.

23) Stevenson, H., \& Harmeling, S. (1990). Entrepreneurial management's need for a more "Chaotic Theory". Journal of Business Venturing, 5, 1-14.

24) Usioboh, A. M. (2008). Basic business management. Lagos: Ladder Press.

25) Wehmeier, S., \& Raaz, O. (2012). Transparency matters. The concept of organizational transparency in the academic discourse. Public Relation Inquiry, 1, 337-366

26) Williams, C. C., \& Nadin, S. (2010). Entrepreneurship and the informal economy: An overview. Journal of Developmental Entrepreneurship, 15(4), 361-378. 